\title{
[特 集]
}

\section{主観的評価値のあいまい性を考慮した ハイブリッド離散選択モデル}

\author{
李 百鎭 $^{1} \cdot$ 藤原章正 $^{2} \cdot$ 張 峻屹 $^{3} \cdot$ 杉恵頼寧 $^{4}$ \\ 1 学生会員 広島大学大学院国際協力研究科開発科学専攻 (†739-8529 東広島市鏡山 1-5-1) \\ E-mail: bjlee@hiroshima-u.ac.jp \\ ${ }^{2}$ 正会員 工博 広島大学大学院教授 国際協力研究科 (干739-8529 東広島市鏡山 1-5-1) \\ E-mail: afujiw@ hiroshima-u.ac.jp \\ 3 正会員 工博 広島大学大学院助教授 国際協力研究科 (T739-8529 東広島市鏡山 1-5-1) \\ E-mail: zjy@hiroshima-u.ac.jp \\ ${ }^{4}$ 正会員 工博 広島大学大学院教授 工学研究科 (下739-8527 東広島市鏡山 1-4-1) \\ E-mail: ysugie@hiroshima-u.ac.jp
}

\begin{abstract}
通常の因子分析では主観的評価值のあいまい性を満足に表現できない，そこで，本研究では， ファジィ理論を用いた因子分析手法の適用により, 主観的評価値のあいまい性を表現することを 試みる. また, 前述の因子分析手法により計算されたファジィ潜在要因に基づき主観的評価值の あいまい性を考慮した新たな離散選択モデル(ハイブリッド離散選択モデル)を提案する. 同モデ ルの効用関数は線形性を仮定した幅を持つ関数形となっている.さらに, 交通情報提供下におけ る交通機関選択の選好意識(SP)データを用いて分析した結果, ファジィ理論を用いた因子分析手 法と提案したハイブリッドモデルの有効性を明らかにした。
\end{abstract}

Key Words : subjective evaluation data, fuzziness, factor analysis, hybrid choice model, fuzzy theory

\section{1. はじめに}

交通行動を記述するための数理モデルはこれまで, 確率効用最大化理論に基づく Predictive choice behavior (PCB) モデルが主流であった. PCB モデル は, 行動の予測可能性を重要視するため, 計測が容 易で観測精度が高く，そして，政策的に制御しやす い定量的要因（例えば，費用，旅行時間，車保有台 数など）をモデルの説明変数として用いることが多 い.これに対して, Behavioral choice (BC) モデルは, $\mathrm{PCB}$ モデルでブラック・ボックスとみなされてきた 個人の意思決定プロセスを解明し, 行動現象をあり のままで論理的に正しく表現しようとしている ${ }^{1)-5) . ~}$ 意思決定プロセスを調べるために，学習や習慣形成 などの客観的に観測可能な要因以外に，個人の認知 心理データ（例えば，嗜好や態度など）という主観 的な要因を用いることも少なくない ${ }^{22-10)}$. しかし, これらの主観的なデータの回答にはあいまい性が多 く含まれると考えられる ${ }^{11) \text { 16). }}$

一方，最近の交通計画分野では，インフラの量的 な拡充の限界から，交通システムの質的な改善（例
えば，公共交通機関の快適性や安全性などのサービ ス改善, ITS による情報提供, 障害者や高齢者のた めのバリアフリー化）が求められている.このよう な交通政策を効果的に評価・展開するためには，快 適性や便利性や安全性などに関する利用者の主観的 な評価が重要になる ${ }^{4)-7) . ~}$

このような背景の中で，交通行動モデルに学習や 習慣形成などの客観的な意思決定プロセス情報を取 り入れると同時に, あいまい性をもつ主観的評価值 も明確に導入する必要性が高まっている，態度や習 慣形成などについては，これまで態度理論などを応 用した研究がある ${ }^{8) 10)}$. 本研究では, 後者の快適性, 便利性, 安全性などに関する利用者の主観的評価值 に存在するあいまい性の表現を中心に研究を進める. ただし, 提案する表現方法は態度などのデータの記 述にも適用可能であると考える.

主観的評価値の測定には，評定尺度方法が主に使 われる.これは，回答者に検討対象を 5 段階や 7 段 階や 10 段階などの尺度に基づき評価してもらう方 法である. 評価尺度は言葉で表すのが通常である ${ }^{11)}$. 例えば， 5 段階評価尺度の場合，「非常に悪い」，「悪 
い」「普通」,「良い」，「非常に良い」という具合で ある。このように計測された主観的評価值に隠れて いる潜在的な要因を見つけ出すために，因子分析が 有効である.しかし，「非常に悪い」や「悪い」の評 定カテゴリーの境界が不明確であるため，これら主 観的評価值のあいまい性を排除することは難しい. そして，通常の因子分析では，このようなあいまい 性を満足に表現することができない 5) 7).

そこで，本研究では主観的評価值に存在するあい まい性を，ファジィ理論に基づき因子分析を行うフ アジィ因子分析手法により表現することを試みる.

ファジィ因子分析は，不明確な限界をもつ主観的 評価值をファジィ集合として表現し，あいまい性が 存在する幅を考慮して, 通常の因子分析を行う ${ }^{12) ~ 14) . ~}$ 通常の因子分析では，主観的評価值間の相関行列を 用いるのに対して，ファジィ因子分析では主観的評 価値の持つあいまい性を考慮するため，「幅」を持っ た相関行列を定義し，その結果として，「幅」を持っ た潜在要因を見つけ出すことができる. 本研究では, このようなファジィ因子分析から得られた「幅」を 持つ潜在要因を，離散選択モデルの効用関数の説明 変数として取り入れ，「幅」を持つ選択確率の算出の 有効性を確認する.

上述のことを鑑みて，本研究は以下のように構成 される。まず，第 2 章では主観的評価值を考慮した 離散選択モデルに関する研究とファジィ理論を応用 した関連研究についてレビューを行う．第 3 章では 本研究で適用したファジィ因子分析手法を説明し, ファジィ潜在要因を考慮した離散選択モデル（ハイ ブリッドモデル）を定式化する. 第 4 章では提案し たモデルの有効性に関する実証的な分析を行う．第 5 章では結論と今後の課題を述べる.

\section{2. 既存の研究}

\section{（1）主観的評価値を取り入れる研究の必要性}

交通行動分析分野においては，1970 年代から心理 的・主観的な潜在要因の重要性が指摘されるように なり，これらの潜在要因を離散選択モデルに導入す る研究が継続的に行われている ${ }^{17)}$. Dobson ${ }^{18)}$ は交通 選択肢に対する個人の主観的な評価を調査する必要 性と，言葉によりその主観的な評価を測る必要性を 主張した.また,この言葉による表現(Linguistic)には， 選択肢の属性，選好の表現，選択肢に関する満足度 の評価，選択肢を選ぶ行動的な意図が含まれている と述べている. McFadden ${ }^{19)}$ は選択行動の意思決定過 程をパスダイアグラムで表し，それに影響を及ぼす
構成概念である知覚, 信念, 情緒, 態度, 選好, 動 機間の因果関係や測定関係を明示的に示した.

今まで，交通分野において離散選択モデルの中に 主観的評価值を取り入れる方法として，主に 2 種類 が挙げられる. 1 つは個人閒における主観評価值の 変動に着目した確率理論に基づくもので，もう 1 つ は主観評価值のあいまい性に着目したファジィ理論 によるものである。以下では，それぞれについてレ ビューを行う。

\section{（2）確率理論による主観的評価值の表現方法}

Ben-Akiva $~^{1)}$ は, 予測可能な選択行動モデル（経 済学, マーケティング, 工学など）と意思決定プロ セスを明確に分析しようとして，選択行動に影響す る様々な要因を離散選択モデルの枠組みの中で総括 的に扱うことのできるハイブリッドモデルを提案し， モデルの説明力を向上させることができると主張し た. Walker ${ }^{2)}$ と Walker \& Ben-Akiva ${ }^{3)}$ は, このハイブ リッドモデルをさらに発展させ, 潜在変数と潜在ク ラスの影響，SP データと RP データとの融合，異質 性などを包括的に扱うことのできる一般化確率効用

(Generalized random utility : GRU) モデルを提案し た.モデルの基本構造を図-1 に示す.このモデルは, 因子分析やより一般的な因果構造分析手法である LISREL モデルを用いた潜在変数モデルと潜在クラ スモデルを特殊形として含めることができる.

因子分析を適用したモデルとして，例えば，Recker \& Golob ${ }^{20)}$ の研究がある.この研究では, 通勤トリッ プにおける交通機関選択行動を分析するため，各交 通機関に対する主観的評価值を用いて因子分析を行 った。そして，潜在要因を，選択肢間に類似性があ る潜在要因と選択肢が固有に持っている潜在要因に 分け，前者を共通変数として，後者を選択肢の固有 変数として定義した．さらに，算出された潜在要因 の因子得点をロジットモデルの中に取り入れた.

Boxall \& Adamowicz ${ }^{21)}$ は, レクレーション活動の動機 や環境に関する主観的な概念に対する異質性を考慮 した潜在クラスモデルを適用した.この研究では, レクレーション活動に関する潜在的異質性を考慮す る動機指標を推定するために因子分析を適用した.

これ以外にも，因子分析を用いた交通行動モデル は多数存在する ${ }^{22) ~ 25)}$. しかし，因子分析を用いたモ デルの問題点の 1 つとして, 潜在要因の予測の困難 さを挙げることができる.これに対して, 森川と佐々 木 ${ }^{4)}$ は観測が可能な要因を用いて潜在要因を同定す るため，LISREL モデルを用いる方法を提案し，都市 間交通機関の利便性と快適性の 2 つの潜在変数を取 り上げ，交通機関選択問題への適用可能性を示した. 


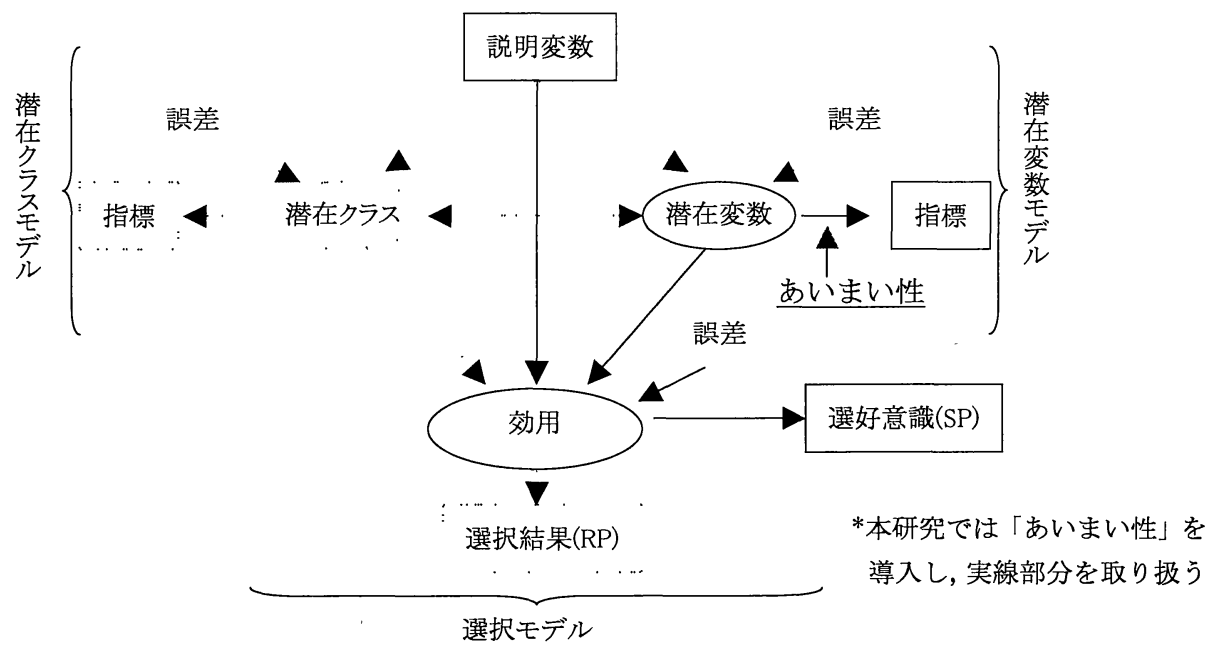

図-1ハイブリッドモデルの基本構造

このモデルの特徴は, LISREL モデルによって観測可 能な要因と不可能な要因の因果関係を定式化し，モ デルの中で推定される未知パラメータを用いて潜在 変数の予測值を計算できることである. しかしなが ら, 段階推定モデルから得た結果は同時推定モデル による結果と顕著なずれが生じているため, モデル 推定上の問題点が課題として挙げられる. また, 同 時推定モデルの推定の複雑さはモデルの実用化を阻 む原因の 1 つとなっている. 河上ら ${ }^{6}$ も交通サービ ス利用者の異質性, 特に知覚構造の異質性を考慮す るため, LISREL モデルを適用した.

\section{（3）ファジィ理論による主観的評価值の表現方法}

ファジィ理論では主観的評価值のあいまい性を扱 うために, 主観的評価值をファジィデータ ${ }^{13), 16), 26), 27) ~}$ として定義する.

秋山と佐佐木 ${ }^{28}$ は, 経路選択行動モデルの構築に 際してファジィ推論の適用可能性を検討した. Lee ら ${ }^{29}$ は, さまざまなファジィ推論方法を用いて交通 情報提供における経路選択行動を分析し, ロジット モデルと比較した結果, ファジィ推論の適用可能性 を実証した. また, 高羽と秋山 ${ }^{30}$ は, 人間の意思決 定プロセスを明示的に表現するため, ファジィ・ル ールに基づくファジィ制約を用いた目的地選択とロ ジットモデルに基づく交通機関選択との統合モデル を提案した. また, Lotan \& Koutsopoulos ${ }^{31)}$ は交通情 報提供における運転者の情報獲得と経路選択行動の プロセスを表現するためにファジィ理論を適用した.

これ以外にも多数研究がなされてきた ${ }^{32)-35)}$. その 中で, 菊地と宇野 ${ }^{35)}$ の研究は興味深い, 彼らは時間 に関する不確実な情報を取り扱うため, 幅という概
念が有効であることに着目し，幅を持つ数值を取り 扱うことができる可能性理論(Possibility Theory)に基 づいて, トリップメーカーの意思決定分析のための 数学的枠組みを提示した. 具体的には, 旅行時間や 到着時刻等の時間要素に含まれる不確実性に対する 人の知覚について検討し，それがトリップのスケジ ユールの設定に及ぼす影響を検証した。また，秋山 と水谷 ${ }^{32}$ は知識ベースモデルの観点から, 確率効用 最大化理論に基づく選択モデルとソフトコンピュー ティグ手法（ファジィ理論，ニューラル・ネットワ 一ク，ファジィ・ニューラル，遺伝的アルゴリズム など）を効果的に融合することで, ファジィ推論型 効用関数をもつハイブリッドモデルを提案した。

\section{（4）本研究の位置づけ}

主観的評価值は 2 面性をもつ.ある個人からみた 場合, 心理的要素や回答環境などの影響でその值が 一般にはっきりしない。このため, 主観評価值をあ いまい現象として扱うべきであろう。一方，主観的 評価值は母集団から抽出する被験者が変わると, そ の回答值の分布が常に同じになる保証がないため, 確率現象（ランダム性のもつ現象）として扱うべき であろう。なお，本研究では，意思決定に関わる不 確実性はあいまい性とランダム性の両方を指す。

そこで, 本研究では交通機関選択を対象に, 主観 評価值のこのような 2 面性に着目し, ファジィ因子 分析手法と離散選択モデルを統合した新たな離散選 択モデルを提案する. 具体的には, 図-1に示すハイ ブリッドモデルの基本構造の実線部分を取り扱うこ とになる。

主観評価值のあいまい性を考慮する点では，秋山 
と水谷 ${ }^{32)}$ のハイブリッドモデルと似通った考え方に 基づいている. しかし, 本研究では, ファジィ因子 分析を適用し，主観評価值間の因果関係を論理的に 表現した上で既存の離散選択モデルと融合するとい うことを考えると，秋山と水谷 ${ }^{32)}$ のモデルとはモデ リング・プロセス上の違いがある.

\section{3. 主観的評価値のあいまい性を考慮した ハイブリッド離散選択モデル}

本研究では, 主観的評価値を表現するために, 因 子分析手法を用いる. 因子分析とは, 主観的評価值 間の相関関係を分析し, それらの背後に潜む潜在因 子を探索しようとする多変量解析の手法である ${ }^{36)}$.

前述のように，一般的には主観的評価值にあいま い性が伴うため, 評価值そのものが幅をもった值と なる.このような主観評価值に関わる潜在要因を抽 出するために, 通常の因子分析では対応できない. そこで, 幅のもった主観評価值に関わる因果構造を 分析する有効な手法としては, ファジィ因子分析手 法がある. 中森と川中 ${ }^{13)}$ は商品の感性的評価構造を 解明するため, ファジィ因子分析手法を初めて提案 した. 具体的には, 言葉として表す評定カテゴリー （感性ワード）間のファジィ距離を同定し, 不明確 な限界をもつ主観的評価值をファジィ集合として表 現した上で因子分析を行う手法である.ここでは, ファジィ因子分析手法を概説した上で，幅を持つ潜 在要因を取り入れた離散選択モデルを定式化する.

\section{（1）ファジィ因子分析}

通常の因子分析を適用する場合, 第 1 段階として, ある潜在因子数のもとで因子負荷量行列 $(A)$ と独自 因子分散行列 $(\Psi)$ 推定值をまず算出する.このと き, データが持つ情報を標本分散共分散行列 $(S)$ ある いは標本相関行列 $(R)$ に集約し，ある規準のもとで データに最も適合するように $A$ と $\Psi$ の各要素の值 を定める. $A$ と $\Psi$ の推定值を得た後に第 2 段階とし ては, 因子の解釈を容易にするために潜在因子の回 転を行う ${ }^{16)}$. ファジィ因子分析手法も上記の 2 段階 を踏む. 異なるのは, あいまい性を取り入れるため, すべての推定值が幅を持って算出される点である.

そこで, 本研究では主観的評価值のあいまい性をモ デルの中に取り入れるために, 最小值と最大值の区 間を用いる值を区間ファジィ数として定義する.

本研究では, 中森と川中 ${ }^{13)}$ により提案されたファ ジィ因子分析手法を適用し, 主観的評価值のあいま い性を表現することにする，この手法は, 相関係数
が区間ファジィ数として表現されるファジィ相関倸 数行列を用いる. 以下では, 中森と川中 ${ }^{13)}$ の研究を 参考に，ファジィ因子分析手法を概説する.

まず，回答者 $(n=1, \cdots, N)$ の評価項目 $(k)$ に対する 主観的評価值 $\left(x_{k}^{n}\right)$ を用いて, 区間ファジィ数として 表されるファジィ相関係数行列 $(\tilde{R})$ を式(1)に基づき 計算する.

$$
\begin{gathered}
\tilde{R}=\left(\left[r_{k l}^{L}, r_{k l}^{R}\right]\right)_{K \times K}=\left[\begin{array}{ccc}
{\left[r_{11}^{L}, r_{11}^{R}\right]} & \cdots\left[r_{K 1}^{L}, r_{K 1}^{R}\right] \\
\vdots & \ddots & \vdots \\
{\left[r_{1 K}^{L}, r_{1 K}^{R}\right] \cdots\left[r_{K K}^{L}, r_{K K}^{R}\right]}
\end{array}\right] \\
r_{k l}^{L}=\max \left\{-1, r_{k l}-\gamma \sigma_{k l}\right\} \\
r_{k l}^{R}=\min \left\{r_{k l}+\gamma \sigma_{k l}+1\right\}
\end{gathered}
$$

ただし， $r_{k l}$ は主観的評価值間の相関行列 $(R)$ の成 分, $\sigma_{k l}$ は $r_{k l}$ の標準偏差, $k$ と $l$ は評価項目 $(k, l=1,2, \ldots, K)$ である. また, $[\cdot, \cdot]$ は区間ファジィ数 を表し， $r_{k l}^{L}$ と $r_{k l}^{R}$ は主観的評価值のあいまい性を考 慮した相関の最小值と最大值である. $\gamma$ はファジィ 度を表すパラメータであり, $\gamma=0$ の場合は通常の因 子分析を意味する。

区間ファジィ数として計算される相関行列 $(\tilde{R})$ の 固有值 $\tilde{\lambda}_{k}$ を求めるため, 式(2)を定義する.

$$
\begin{aligned}
\tilde{R}-D^{2} & =\left(\tilde{s}_{k l}\right)=\left(\left[s_{k l}^{L}, s_{k l}^{R}\right]\right) \\
& =\left(\left[r_{k l}^{L}-d_{k l}^{2}, r_{k l}^{R}-d_{k l}^{2}\right]\right)
\end{aligned}
$$

ここで, $D=\operatorname{diag}\left(d_{k}\right)$ は独自因子の荷重行列， $d_{k}$ は 独自因子である.

潜在因子数が $P$ 個あると仮定すると, ファジィ固 有值 $\left(\tilde{\lambda}_{p}\right)$ は区間ファジィ数として, 以下の最適化問 題を解くことにより求めることができる.

$$
\begin{gathered}
\lambda_{p}^{L} \text { の最小化 }(p=1, \cdots, P) \\
\text { 制約条件 } 0 \leq \lambda_{p}^{L} \leq \lambda_{p} \\
\left|\lambda_{p}^{L} e_{p k}\right| \leq \max \left\{\left|\sum_{k=1}^{K} s_{p k}^{L} e_{p k}\right|,\left|\sum_{k=1}^{K} s_{p k}^{R} e_{p k}\right|\right\} \\
\lambda_{p}^{R} \text { の最大化 }(p=1, \cdots, P) \\
\text { 制約条件 } \lambda_{p} \leq \lambda_{p}^{R} \\
\left|\lambda_{p}^{R} e_{p k}\right| \geq \min \left\{\left|\sum_{k=1}^{K} s_{p k}^{L} e_{p k}\right|,\left|\sum_{k=1}^{K} s_{p k}^{R} e_{p k}\right|\right\}
\end{gathered}
$$

ここで $\lambda_{p}$ と $\left(e_{p k}\right)$ はそれぞれ $\gamma=0$ のときの平均固 有値と平均固有值ベクトルである.

$\tilde{\lambda}_{p}$ を求めた後に, ファジィ因子負荷量 $\tilde{A}$ を式(5) のように推定する.

$$
\begin{aligned}
\tilde{\mathrm{A}}=\left(\tilde{\mathrm{a}}_{\mathrm{pk}}\right) & =\left(\left[\mathrm{a}_{\mathrm{pk}}^{\mathrm{L}}, \mathrm{a}_{\mathrm{pk}}^{\mathrm{R}}\right]\right) \\
& =\left\{\begin{array}{l}
{\left[\sqrt{\lambda_{\mathrm{p}}^{\mathrm{L}}} \mathrm{e}_{\mathrm{pk}}, \sqrt{\lambda_{\mathrm{p}}^{\mathrm{R}}} \mathrm{e}_{\mathrm{pk}}\right], \mathrm{e}_{\mathrm{pk}} \geq 0} \\
{\left[\sqrt{\lambda_{\mathrm{p}}^{\mathrm{R}}} \mathrm{e}_{\mathrm{pk}}, \sqrt{\lambda_{\mathrm{p}}^{\mathrm{L}}} \mathrm{e}_{\mathrm{pk}}\right], \mathrm{e}_{\mathrm{pk}}<0}
\end{array}\right.
\end{aligned}
$$


また，回転行列 $T=\left(t_{p k}\right)$ を用いて，回転後のファ ジィ因子負荷量 $(\widetilde{B})$ を求める.

$$
\begin{aligned}
& \tilde{B}=\left(\tilde{b}_{p k}\right)=\left(\left[b_{p k}^{L}, b_{p k}^{R}\right]\right)=\sum_{p=1}^{P} t_{p k} \times\left[a_{p k}^{L}, a_{p k}^{R}\right] \\
& t_{p k} \times\left[a_{p k}^{L}, a_{p k}^{R}\right]= \begin{cases}{\left[t_{p k} a_{p k}^{L}, t_{p k} a_{p k}^{R}\right],} & t_{p k} \geq 0 \\
{\left[t_{p k} a_{p k}^{R}, t_{p k} a_{p k}^{L}\right],} & t_{p k}<0\end{cases}
\end{aligned}
$$

上記に説明したファジィ因子分析手法の推定は少 し複雑のように見えるが，実用的には，区間ファジ イ数として式(1)の相関行列を計算した後, 式(3)〜(4) を満たす手順を踏むことで, 通常の因子分析手法の 推定に使う統計プログラムで推定が可能である.

区間ファジィ数として算出された因子負荷量閒の ファジィ距離 $\left(\tilde{d}_{k l}\right)$ は式(7)によって計算する.

$$
\begin{gathered}
\tilde{d}_{k l}=\left(\left[d_{k l}^{L}, d_{k l}^{R}\right]\right)=\left\{\left\{\sum_{p=1}^{P}\left(\delta_{p k l}^{L}\right)^{2}\right\}^{\frac{1}{2}},\left\{\sum_{p=1}^{P}\left(\delta_{p k l}^{R}\right)^{2}\right\}^{\frac{1}{2}}\right) \\
\delta_{p k l}^{L}=\min \left\{|T 1-T 2| ; \forall T 1, \forall T 2 \in \tilde{b}_{p k}\right\} \\
\delta_{p k l}^{R}=\max \left\{|T 1-T 2| ; \forall T 1, \forall T 2 \in \tilde{b}_{p k}\right\}
\end{gathered}
$$

このように, ファジィ因子分析の場合, 因子負荷 量が区間ファジィ数として与えられる。これらの主 観的評価值に関わる潜在要因を抽出するため, Fuzzy C-means clustering (FCM) 手法 ${ }^{37}$ を用いる. FCM を実 行するため, 本研究ではファジィ数として計算され た因子負荷量間の距離 $\left(\tilde{d}_{k l}\right)$ の平均值を用いる.

\section{（2）新たなハイブリッド離散選択モデルの定式化}

因子分析から得た潜在因子に対する回答者の主観 的評価值は, 因子得点によって表される.また, 因 子得点は潜在変数として離散選択モデルに導入され る. 潜在因子 $q$ に対する因子得点は式(8)により計算 される ${ }^{20)}$.

$$
\bar{f}_{i q}^{n}=\sum_{k \in K} x_{i k}^{n} b_{i q k} \lambda_{i q}^{-1}+\eta_{i q}^{n}
$$

ここで, $\bar{f}_{l q}^{n}$ は個人 $n$ が選択肢 $i$ の潜在因子 $q$ に対す る因子得点 (潜在変数), $x_{i k}^{n}$ は選択肢 $i$ の評価項目 $k$ に対する主観的評価值, $b_{l q k}$ は潜在因子 $q$ に対する評 価項目 $k$ の回転後の因子負荷量, $\lambda_{i q}$ は潜在因子 $q$ の 固有值, $\eta_{i q}^{n}$ は考慮しない変数による誤差項である.

本研究では, $\bar{f}_{i q}^{n}$ が選択行動に影響する他の要因と 独立であると仮定し，選択肢効用関数を式(9)のよう に定義する.

$$
U_{t}^{n}=\sum_{m \in M} \beta_{m} x_{i m}^{n}+\sum_{q=Q} \alpha_{q} \bar{f}_{i q}^{n}+\xi_{t}^{n}
$$

ここで, $U_{i}^{n}$ は個人 $n$ の選択肢 $i$ の効用関数, $x_{m}^{n}$ は 選択肢 $i$ の交通サービス水準 (総数: $M$ 個), $\beta_{m}$ と $\alpha_{q}$ はパラメータ, $\xi_{l}^{n}$ は効用の誤差項, $Q$ は潜在変数 $\bar{f}_{i q}^{n}$ の数である. $x_{i m}^{n}$ と $\bar{f}_{i q}^{n}$ はそれぞれ異なる性質の行動に関わる変 数である場合, 式(9)が成り立つと考えられる. 後述 のように, 本研究では, $x_{m}^{n}$ は選好意識調査における 交通機関サービス水準値, $\bar{f}_{i q}^{n}$ は実際の交通機関サー ビス水準に関する主観的評価值に関わる潜在変数で ある.このようなことを考えると, 本研究では, 効 用関数を式(9)のように特定化しても差し支えない. ただし, $\bar{f}_{l q}^{n}$ が選択行動に影響する他の要因 $x_{i m}^{n}$ と相 関する場合, 式(9)を改良する必要がある.例えば, $x_{m}^{n}$ のパラメータ $\beta_{m}$ を式(8)の関数として定義すること ができる.こうすることにより,$x_{m}^{n}$ のパラメータ (評 価重み）に関する個人間の異質性を表現することが できる．ただし，これは本研究の検討範囲を超える ため, その検証については今後の研究課題としたい.

式(8)を式(9)に代入すると, 効用関数は式(10)のよ うに変換される.

$$
\begin{gathered}
U_{i}^{n}=\sum_{m \in M} \beta_{m} x_{i m}^{n}+\sum_{q=Q} \alpha_{q} f_{i q}^{n}+\varepsilon_{l}^{n} \\
f_{i q}^{n}=\sum_{k \in K} x_{i k}^{n} b_{i q k} \lambda_{i q}^{-1} \\
\varepsilon_{l}^{n}=\sum_{q=Q} \alpha_{q} \eta_{l q}^{n}+\xi_{t}^{n}
\end{gathered}
$$

ここで, $\varepsilon_{i}^{n}$ は式(8)と式(9)の誤差項からなる新たな誤 差項である.

このように, 効用式(9)の誤差項 $\xi_{i}^{n} に$, 潜在変数を 表す式(8)の誤差項 $\eta_{1 q}^{n}$ が加わることで, 誤差構造は複 雑になっている. しかし, 従来の誤差項 $\xi_{l}^{n}$ は省略さ れた変数の影響も含むことを考えると, 式(9)に式(8) を取り入れることにより，誤差項の影響はかえって 減っていく可能性がある.

本研究ではさらに, $Q$ 個の潜在変数を共通属性に 関する潜在変数（ $Q_{G}$ 個）と選択肢固有属性に関する 潜在変数 $\left(Q_{S}\right.$ 個) に分けて, 効用関数式(10)を式(11) のように再定義する.

$$
U_{i}^{n}=\sum_{m \in M} \beta_{m} x_{i m}^{n}+\sum_{q=Q_{G}} \alpha_{q} f_{l q}^{n}+\sum_{q=Q_{S}} \alpha_{q} f_{i q}^{n}+\varepsilon_{l}^{n}
$$

本研究では，主観評価值のあいまい性を考慮する ため, ファジィ因子分析手法を適用し，区間ファジ イ数として与える潜在変数を用いることが必要であ る. このため, 本研究で用いる効用関数をさらに, 式(12)によって定義する.

$$
\begin{aligned}
\widetilde{U}_{i}^{n}=\sum_{m \in M} \widetilde{\beta}_{m} x_{i m}^{n}+\sum_{q=Q_{G}} \widetilde{\alpha}_{q} \tilde{f}_{i q}^{n}+\sum_{q=Q_{S}} \widetilde{\alpha}_{q} \widetilde{f}_{i q}^{n}+\varepsilon_{l}^{n} \\
\widetilde{U}_{l}^{n}=\left[U_{i}^{n L}, U_{i}^{n R}\right]=\sum_{m \in M}\left[\beta_{m}^{L}, \beta_{m}^{R}\right] x_{i m}^{n} \\
+\sum_{q=Q_{G}}\left[\alpha_{q}^{L}, \alpha_{q}^{R}\right] \cdot\left[f_{i q}^{n L}, f_{i q}^{n R}\right] \\
+\sum_{q=Q_{S}}\left[\alpha_{q}^{L}, \alpha_{q}^{R}\right] \cdot\left[f_{i q}^{n L}, f_{i q}^{n R}\right]+\varepsilon_{i}^{n}
\end{aligned}
$$


ここで, $\tilde{f}_{l q}^{n}$ はファジィ因子分析により区間ファジィ 数として計算された因子得点（潜在変数）, $[\cdot, \cdot]$ は最 小值と最大值を表す区間ファジィ数で, $\mathrm{L}$ が最小值, $\mathrm{R}$ が最大值をそれぞれ表す添字である. 交通サービ ス水準変数のパラメータ $\beta_{m}$ も区間で表現される理 由は, 区間ファジィ数として与えられた因子得点 $\tilde{f}_{i q}^{n}$ をモデルの中に取り入れることにより，パラメータ $\beta_{m}$ の推定值にも影響を及ぼすからである.

なお, 区間ファジィ数としての潜在変数 $\tilde{f}_{i q}^{n}$ は, 式 (8)を用いて最小值と最大值のそれぞれに対して計算 される。

ここで, 式(12)の誤差項 $\varepsilon_{1}^{n}$ が独立で同一なガンべ ル分布に従うと仮定すると, 区間ファジィ数の 1 つ 1 つに対する通常のロジットモデルと同じ式が得ら れる. 本研究では交通機関選択を対象に, 式(12)を取 り入れた離散選択のロジットモデル（本研究で提案 するハイブリッド離散選択モデル）を，区閒ファジ イ数として与えられた潜在変数の最小值と最大值の それぞれに対して, 通常の最尤推定法に基づき推定 する.

\section{4. 事例研究}

本研究では広島市の新交通システム（アストラム ライン：NTS）の沿線住宅地における交通機関選択 を対象に, 自動車（乗用車）の遅れ所要時間情報提 供が自動車と NTS の選択行動に与える影響を取り上 げ, 提案モデルの有効性を検証する.

深刻な道路交通渋滞を緩和し，モビリティの確保 を図り, 環境問題を改善するため, NTS などの公共 交通機関の利便性を向上させ, ITS 技術を活かした マルチモーダル情報の提供などの交通政策が各地で 検討・実施されている．このような交通政策を今後 効果的に実施するため, 利用者の交通行動変化に及 ぼす影響を評価する必要性がある，このため，旅行 時間の短縮効果や道路交通渋滞情報による交通行動 の変化の分析だけではなく, 交通情報提供に対する 満足度, NTS の快適性や駅までのフィーダー交通機 関の利便性に対する満足度などの主観的評価要因が 意思決定プロセスに与える影響についても明確にす ることが望まれる。

本研究では, 自動車利用者を対象にして, 自動車 の遅れ所要時間情報提供による自動車と NTS の選択 行動の変化を分析する. また, 交通機関選択の意思 決定に影響する主観的評価要因として, 自動車, NTS, フィーダーバスの運行満足度や自動車の交通情報提 供の満足度などを取り上げる.
表-1 主観的評価項目

\begin{tabular}{|c|c|}
\hline 交通機関 & 評価項目 \\
\hline 自動車 & $\begin{array}{l}\text { (1)目的地までの所要時間 } \\
\text { (2)渋帯状況 (渋滞場所と渋滞長) } \\
\text { (3)ラジオによる道路交通情報提供の現状 } \\
\text { (4)テレビによる道路交通情報提供の現状 }\end{array}$ \\
\hline $\begin{array}{c}\text { フィーダー } \\
\text { バス }\end{array}$ & $\begin{array}{l}\text { (5)普段の日の運行ダイヤの正確さ } \\
\text { (6)雨や雪の日の運行ダイヤの正確さ } \\
\text { (7)運行本数 } \\
\text { (8)所要時間(速さ) } \\
\text { (9)運賃 }\end{array}$ \\
\hline NTS & $\begin{array}{l}\text { (10)雨や雪の日の運行ダイヤの正確さ } \\
\text { (11)運行本数 } \\
\text { (12)運行時閒帯 (始発・終電の時間) } \\
\text { (13)所要時間 (速さ) } \\
\text { (14)運賃 }\end{array}$ \\
\hline
\end{tabular}

\section{(1) データの概要}

著者らは 1999 年に広島市安佐南区に住む住民を 対象に，市内中心部への旅行時間情報が提供された . 場合における公共交通機関利用意向についてアンケ 一ト調查を実施した ${ }^{38)}$. 調查は 2 回に分け実施され た. 1 回目の調査では, 個人属性, 普段の利用交通 機関, 移動目的, 更に自動車利用者に対しては将来 におけるNTS の利用可能性などを尋ねた，2回目の 調査では, 情報提供の必要性や必要な情報の内容, 自動車利用者に対しては情報提供下における自動車 と NTS に関する選好意識(SP)を調べた。

また, 自動車, NTS, NTS 駅までのフィーダーバ スに関する満足度に関する主観的評価として, 表一 1 に示すような評価項目について被験者に回答して もらった. 各評価項目については,「満足」,「やや満 足」,「普通」,「やや不満足」,「不満足」の 5 段階評 価尺度を用いて 5 から 1 の数字で評価してもらった。 前述の主観的評価值は, 通常の段階評価法で計測 された值である.しかし, 個人が表-1に挙げる各交 通機関の評価項目のそれぞれに対して満足か不満か を答えることができても, 満足・不満の程度を必ず しも確定的に評価できるわけではない. また, 例え ば，同じ「やや不満」という評価尺度についても， 個人によってその言葉が意味する範囲に対する認識 が異なると考えられる. その結果，このような主観 的評価值にはあいまい性が伴うと考えるのは現実的 であると思われる，そこで，本研究では，それぞれ の主観的評価值をファジィ数として処理する.

本研究では, このような主観的評価值を導入した 離散選択モデルにより交通機関選択行動を記述する ことの精緻化を狙いとしているが, 予測を行う際に, 
表-2 SP カードの設定

\begin{tabular}{l|c|c|c|c}
\hline \multicolumn{1}{c|}{ カード } & SP1 & SP2 & SP3 & SP4 \\
\hline $\begin{array}{l}\text { 自動車の遅れ } \\
\text { 時間情報の有無 }\end{array}$ & なし & あり & あり & あり \\
\hline $\begin{array}{l}\text { 自動車の遅れ } \\
\text { 時間(分) }\end{array}$ & - & 0 & 10,20 & 30,40 \\
\hline $\begin{array}{l}\text { NTS の所要 } \\
\text { 時間(分) }\end{array}$ & 20 & 20 & 20 & 20 \\
\hline
\end{tabular}

例えば，後述のような将来の交通サービス水準の変 化に伴う個人の主観的評価值の変化をどのように予 測すればよいかという問題が生じる.これについて は, 交通サービス水準と主観的評価值との因果関係 を別のモデリング手法により事前に評価した上で交 通機関選択モデルに導入する方法などが考えられる. ただし, 本研究では離散選択モデルの枠組みの中で, 主観的評価值をファジィ因子分析により表現するこ との有効性を検証するため, モデルの需要予測への 適用性については今後の研究課題としたい.

SP 調査では, 自動車の遅れ時間情報の有無, 自動 車の遅れ時間, NTS の所要時間の条件を設定した 4 種類のカードを被験者に提示し, 対象地域から市内 中心部に向かう場合を想定して自動車とNTSの選択 意向を尋ねた。なお，自動車の所要時閒については オフピーク時の実績值を記入してもらった. SP カー ドの設定条件を表-2 に示す. カード SP1 は自動車の 遅れ時間情報が提供されていない通常の交通状況を 想定している.これに対して，SP2 では遅れが生じ ていない（遅れ時間が 0 分）情報の提供を, SP3 で は軽い遅れが生じている（遅れ時間 10，20 分）情 報の提供を, SP4 では著しく遅れが生じている（遅 れ時間 30,40 分）情報の提供をそれぞれ想定して いる. NTS の所要時間については，定時性が高いた めすべてのカードにおいて 20 分とした. なお, 自動 車の総所要時間は，通常の所要時間と遅れ時間の和 とする.

\section{（2）ファジィ因子分析の推定結果}

図-2 は，ファジィ度 $\gamma$ を仮にそれぞれ $0.0 ， 0.2$, 0.6 に設定した場合の区間ファジィ固有值の推定結 果を示している. ファジィ度 $\gamma=0.0$ の場合は，通常 の因子分析の結果と一致する。この図から分かるよ うに，ファジィ度が大きくなるにつれ，最小と最大 固有值とのギャップが拡大している様子が確認でき る.これは, 主観的評価値のあいまい性が増すこと を表している.

図-3 と図-4 はそれぞれ $\gamma=0.0$ と $\gamma=0.6$ の場合に おける潜在因子の因子得点をプロットしている. 図

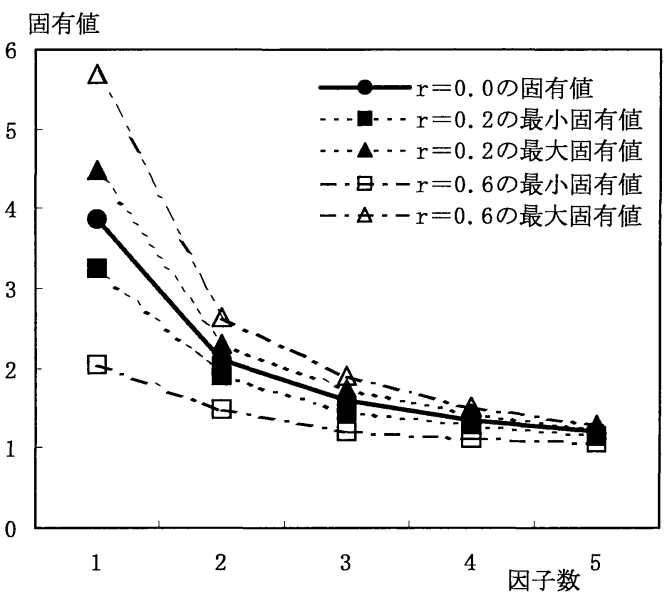

図-2 区間ファジィ固有值 $(\gamma=0.0,0.2,0.6)$

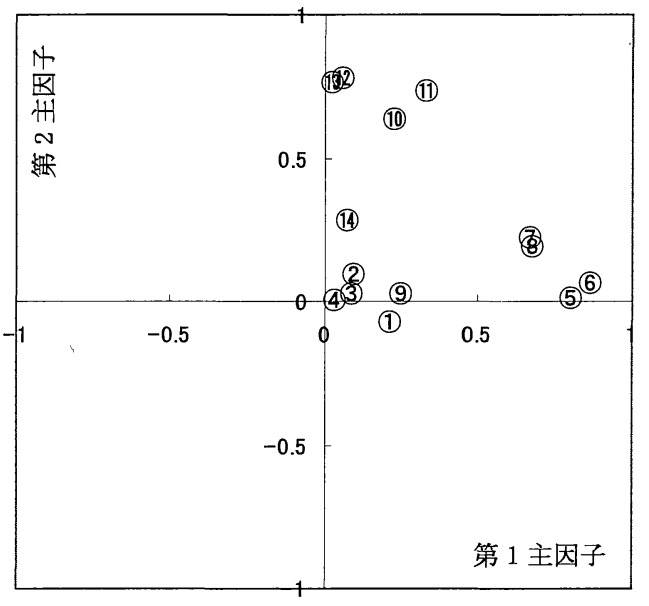

図-3 通常の因子プロット $(\gamma=0.0)$

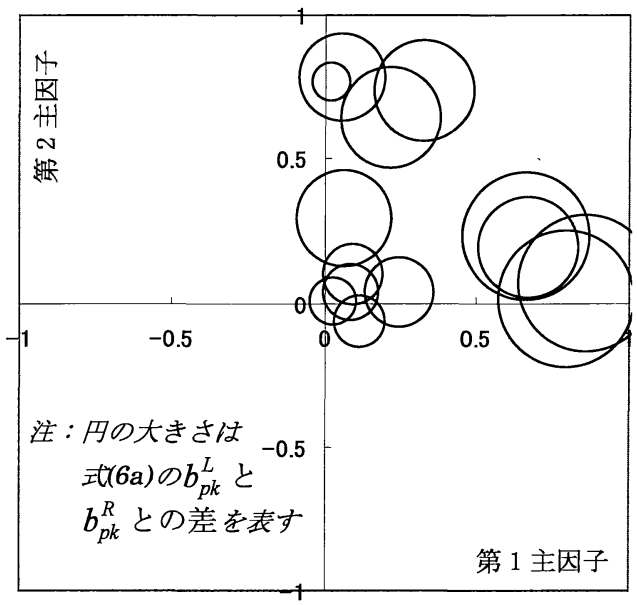

図-4 ファジィ因子プロット $(\gamma=0.6)$ 
-3 と図-4 を比較してみると, ファジィ度が増すこと により，区間ファジィ数に対応した潜在因子負荷量 の最大值と最小值との差異が大きくなることが読み 取れる. 各潜在因子は主観的評価值によって定義さ れることを考えると，ファジィ度が主観評価值に内 在するあいまいさの程度を表すと解釈することがで きる.

本研究では, 自動車利用者を対象に各交通手段の 満足度を尋ねたため, 図-4 から分かるように，自動 車の主観的評価值 (1)(2)(3)(4) はファジィ度によって 変動があまり見られない. NTS の所要時間に関する 主観評価値(13)に対しても変動幅が小さい.これは, 普段よく利用する自動車と定時性の高いNTS の所要 時間に存在するあいまい性が小さいことを示唆する。 一方, NTS の所要時間以外の主観評価値, 特にフィ ーダーバスの主観評価值の変動幅が大きい，このよ うなあいまい性の異なる潜在因子が意思決定者の選 択行動に及ぼす影響も異なってくると考えられる.

前述のことから，ファジィ因子分析手法により， 交通機関選択に影響すると思われる主観評価值のあ いまい性を捉えることができると言える.

表-3 に, ファジィ対象閒のファジィ距離と FCM の推定結果を表す.メンバーシップ值から判断する と, フィーダーバスの「雨や雪の日の運行ダイヤの 正確さ(6)」と「運行本数 (7) 」以外, 明確に各潜在 クラスにばらついていることが分かる，図 -3 , 図-4 と表-3 に示している FCM の推定結果から, 次のよ うな潜在因子を定義することができる.

第 1 主因子：自動車交通情報の満足度

第 2 主因子 : 自動車の運行満足度

第 3 主因子 : フィーダーバスの運行満足度

第 4 主因子 : NTS とフィーダーバスの運賃満足度 第 5 主因子：NTS の運行満足度

\section{（3）新たなハイブリッド離散選択モデルの推定結果}

ここでは，前述のファジィ因子分析から算出され た潜在因子を交通機関選択モデルの効用関数に取り 入れ, 提案モデルの有効性を検証する. 表-4に推定 に用いた説明変数の一覧を示す.

本研究では, 潜在変数（潜在因子の因子得点））を 選択肢間に共通する要因（共通変数）と選択肢別の 固有要因（固有変数）に分ける. 具体的には, 自動 車, NTS, フィーダーバスの運行満足度は共通変数, 自動車交通情報提供の満足度は自動車の固有変数, NTS とフィーダーバスの運賃満足度はNTS の固有変 数として適用した. $W$ は, NTS の運行満足度とフィ ーダーバスの運行満足度がどのくらいの割合で影響 するのかを表現する相対尺度推定係数である.
表-3 ファジィ対象閒のファジィ距離と FCM の推定結果

\begin{tabular}{|c|c|c|c|c|c|c|}
\hline 評価 & \multicolumn{5}{|c|}{ メリバーシップ 值 (クラスター) } & \multirow{2}{*}{ フアジィ距離 } \\
\hline 目 & 1 & 2 & 3 & 4 & 5 & \\
\hline (3) & 0.99 & 0.01 & 0.00 & 0.00 & 0.00 & {$[0.00,0$.} \\
\hline 4) & 0.99 & 0.01 & 0.00 & 0.00 & 0.00 & {$[0.03,0.28]$} \\
\hline (1) & 02 & 0.95 & 01 & 0.01 & 0.01 & {$[0.00,0.23]$} \\
\hline (2) & 0.02 & 0.95 & 0.01 & 0.01 & 0.01 & {$[0.18,0.46]$ (1) $\Leftrightarrow(2)$} \\
\hline (5) & 01 & 0.01 & 0.95 & 0.02 & 0.01 & {$[0.00,0.39]$ (5) $\Leftrightarrow$ (5) } \\
\hline (6) & 03 & 0.04 & 0.83 & 0.05 & 0.05 & 53] (5) $\Leftrightarrow$ (6) \\
\hline (7) & 0.02 & 0.03 & 0.88 & 0.03 & 0.04 & {$[0.11,0.61]$ (5) $\Leftrightarrow(7)$} \\
\hline (8) & .01 & 0.02 & 93 & 0.02 & 0.03 & 47] (5) $\Leftrightarrow(8)$ \\
\hline (9) & 01 & 0.01 & 0.02 & 0.93 & 0.03 & {$[0.00,0.26]$ (9) $\Leftrightarrow$ (9) } \\
\hline (14) & .01 & 0.01 & 0.02 & 0.94 & 0.02 & {$[0.11,0.60]$ (9) $\Leftrightarrow$ (14) } \\
\hline (10) & 16 & 0.08 & 0.17 & 0.12 & 0.47 & {$[0.00,0.35]$ (10) $\Leftrightarrow(10)$} \\
\hline (11) & 0.09 & 0.07 & 0.16 & 0.11 & 0.57 & {$[0.17,0.61]$ (10) $\Leftrightarrow$ (11) } \\
\hline (12) & .01 & 0.01 & 0.01 & 0.02 & 0.95 & {$[0.48,0.88] \quad(10) \Leftrightarrow(12)$} \\
\hline (13) & .02 & 0.02 & 02 & .04 & 0.90 & {$[0.53,0.89] \quad(10) \Leftrightarrow(13)$} \\
\hline
\end{tabular}

表-4 説明変数一覧表

\begin{tabular}{l|l}
\hline $\mathrm{TT}$ & 自動車とNTSの所要時間 (共通変数) \\
\hline $\mathrm{AGE}$ & 年齢(自動車固有変数) \\
\hline $\mathrm{DT}$ & 自動車の遅れ時間情報(自動車固有変数) \\
\hline DUI & $\begin{array}{l}\text { 交通情報ダミー(自動車固有変数) } \\
\text { 交通情報が提供されている場合 } 1 \\
\text { 交通情報が提供されていない場合 } 0\end{array}$ \\
\hline $\mathrm{CC}$ & 定数項(自動車固有変数) \\
\hline SL & $\begin{array}{l}\text { 自動車, NTS, フィーダーバスの } \\
\text { 運行満足度(共通変数) }\end{array}$ \\
\hline LCI & 自動車交通情報の満足度(自動車固有変数) \\
\hline W & $\begin{array}{l}\text { NTSとフィーダーバスの } \\
\text { 運賃満足度(NTS固有変数) } \\
\text { NTSとフィーダーバスの運行満足度の } \\
\text { 相対尺度推定係数 (NTS固有変数) }\end{array}$ \\
\hline
\end{tabular}

自動車の遅れ時間情報が交通機関選択行動に及ぼ す影響を調べるため, 以下の 3 つのケースを検討対 象とする.

ーケース 1 (SP1)：普段の交通状沉，つまり，遅れ時

間情報が提供されていない場合における潜在因 子の影響力を調べるためのものである.

ーケース $2(\mathrm{SP} 1+\mathrm{SP} 2)$ : 遅れが生じていないという交 通情報が提供された場合における潜在因子の影 響力を調べるためのものである.

ーケース $3(\mathrm{SP} 2+\mathrm{SP} 3+\mathrm{SP} 4)$ : 遅れ時間の交通情報が 提供された場合における潜在因子の影響力を調 べるためのものである.

そして, 以下の 3 種類のモデルをそれぞれ推定し, その結果を表-5 と表-6 に示す.

一モデル $1:$ 潜在因子を考慮しないモデル

一モデル $2:$ 通常の因子分析から算出された潜在因子

を取り入れたモデル

一モデル $3:$ ファジィ因子分析から算出された潜在因

子を取り入れたモデル 
表-5 モデル 1 とモデル 2 の推定結果

\begin{tabular}{|c|c|c|c|c|c|c|c|c|c|c|c|c|}
\hline \multirow{3}{*}{$\begin{array}{l}\text { データ } \\
\text { 説明変数 }\end{array}$} & \multicolumn{6}{|c|}{ モデル 1} & \multicolumn{6}{|c|}{ モデル 2} \\
\hline & \multicolumn{2}{|c|}{ ケース 1} & \multicolumn{2}{|c|}{ ケース2 } & \multicolumn{2}{|c|}{ ケース3 } & \multicolumn{2}{|c|}{ ケース 1} & \multicolumn{2}{|c|}{ ケース 2} & \multicolumn{2}{|c|}{ ケース 3} \\
\hline & 推定值 & $\mathrm{t}$ 值 & 推定值 & $\mathrm{t}$ 值 & 推定值 & $\mathrm{t}$ 值 & 推定值 & $\mathrm{t}$ 值 & 推定值 & $\mathrm{t}$ 值 & 推定值 & $\mathrm{t}$ 值 \\
\hline TT & -0.031 & 1.447 & -0.027 & 1.824 & -0.015 & 1. 147 & -0.029 & 1.222 & -0.025 & 1.639 & -0.011 & 0.797 \\
\hline AGE & -0.196 & 1. 343 & -0.174 & 0.689 & -0.161 & 1. 735 & -0.173 & 0.162 & -0.130 & 1. 157 & -0.143 & 1. 456 \\
\hline DT & & & & & -0.071 & 7. 992 & & & & & -0.084 & 7. 785 \\
\hline DUI & & & 0.640 & 2. 442 & & & & & 0.762 & 2. 634 & & \\
\hline $\mathrm{CC}$ & 1.480 & 1.934 & 1.317 & 2. 378 & 1.718 & 3.455 & 1. 362 & 1.617 & 1. 108 & 1.854 & 1.723 & 3. 179 \\
\hline$\overline{\mathrm{SI}}$ & & & & & & & 0.325 & 1.340 & 0.211 & 1.303 & 0.386 & 2.973 \\
\hline SLCI & & & & & & & 0.735 & 3. 378 & 0.720 & 4.658 & 0.720 & 5. 747 \\
\hline SLF & & & & & & & 0.461 & 2. 352 & 0.454 & 3. 042 & 0.334 & 2. 469 \\
\hline W & & & & & & & 0.620 & 3.206 & 0.558 & 3. 042 & 0.295 & 2. 406 \\
\hline 初期対数尤度 & -88 & & -177 & .45 & -266. & 17 & -88. & & -177 & .45 & -266 & .17 \\
\hline 最終対数尤度 & -85 & & -166 & .26 & -219 & 89 & -74 . & & -144 & .68 & -189 & .82 \\
\hline 尤度比 & 0.0 & & 0.0 & & 0.1 & & 0.1 & & 0.1 & & 0.2 & \\
\hline 自由度調整済み尤度比 & 0.0 & & 0.0 & & 0.15 & & 0.0 & & 0.1 & & 0.2 & \\
\hline サンプル数 & 12 & & 25 & & 38 & & 12 & & 25 & & 38 & \\
\hline
\end{tabular}

表-6 モデル 3 の推定結果

\begin{tabular}{|c|c|c|c|c|c|c|}
\hline \multirow{2}{*}{$\begin{array}{l}\text { データ } \\
\text { 説明変数 }\end{array}$} & \multicolumn{2}{|c|}{ ケース1 } & \multicolumn{2}{|c|}{ ケース2 } & \multicolumn{2}{|c|}{ ケース3 } \\
\hline & 推定値 & $\mathrm{t}$ 値 & 推定値 & $\mathrm{t}$ 值 & 推定値 & $\mathrm{t}$ 值 \\
\hline$\overline{\mathrm{TT}}$ & {$[-0.029,-0.029]$} & {$[0.235,1.213]$} & {$[-0.026,-0.025]$} & {$[1.666,1.621]$} & {$[-0.011,-0.110]$} & {$[0.803,0.794]$} \\
\hline AGE & {$[-0.168,-0.178]$} & {$[1.027,1.101]$} & {$[-0.123,-0.136]$} & {$[1.078,1.211]$} & {$[-0.142,-0.146]$} & {$[1.430,1.482]$} \\
\hline DT & & & & & {$[-0.085,-0.084]$} & {$[7.796,7.779]$} \\
\hline DUI & & & {$[0.767,0.759]$} & {$[2.643,2.631]$} & & \\
\hline $\mathrm{CC}$ & {$[1.336,1.384]$} & {$[1.569,1.643]$} & {$[1.073,1.133]$} & {$[1.778,1.899]$} & {$[1.719,1.734]$} & {$[3.151,3.202]$} \\
\hline$\overline{\text { SI }}$ & {$[0.272,0.364]$} & {$[1.322,1.481]$} & {$[0.172,0.242]$} & {$[1.208,1.416]$} & {$[0.327,0.421]$} & {$[2.886,3.069]$} \\
\hline SLCI & {$[0.632,0.829]$} & {$[3.416,3.384]$} & {$[0.613,0.811]$} & {$[4.701,4.659]$} & {$[0.603,0.822]$} & {$[5.668,5.883]$} \\
\hline SLF & {$[0.370,0.523]$} & {$[2.117,2.455]$} & {$[0.356,0.516]$} & {$[2.714,3.167]$} & {$[0.250,0.388]$} & {$[2.093,2.630]$} \\
\hline W & {$[0.640,0.606]$} & {$[3.250,3.200]$} & {$[0.574,0.545]$} & {$[4.083,4.039]$} & {$[0.296,0.295]$} & {$[2.338,2.469]$} \\
\hline 初期対数尤度 & -88. & & -177 & & -266 & \\
\hline 最終対数尤度 & {$[-73.66$} & $-74.38]$ & {$[-143.86$} & $-145.08]$ & {$[-189.58$} & $-189.82]$ \\
\hline 尤度比 & {$[0.170$} & $0.162]$ & {$[0.189$} & $0.182]$ & {$[0.288$} & $0.287]$ \\
\hline 自由度調整済み尤度比 & {$[0.092$} & $0.083]$ & {$[0.145$} & $0.137]$ & {$[0.259$} & $0.257]$ \\
\hline サンプル数 & 12 & & 25 & & 38 & \\
\hline
\end{tabular}

上述のモデルの推定結果について，以下のように 考察を行う.

\section{a）モデルの精度について}

モデル 3 については, ファジィ度 $\gamma=0.6$ の場合に 自由度調整済み尤度比が最も高い。このことから， 本研究で用いる主観的評価値に内在するあいまい性 の大きさが伺える.ここでは，表-5に $\gamma=0.6$ の結果 のみを示す。

潜在因子を考慮しないモデル 1 の自由度調整済み 尤度比が非常に小さい值（0.004）となってしまった のは，取り入れる説明変数が不足していると考えら れる.ただし，同様な説明変数を取り入れた各モデ ルを比較するには支障がないと思われる．モデル 1 と比べて, モデル 2 の精度（自由度調整済み尤度比） は，ケース 1 では 0.004 から 0.085 に，ケース 2 で は 0.041 から 0.140 に,ケース 3 では 0.159 から 0.257 にそれぞれ向上した。このことから，潜在因子を取
り入れることにより，モデルの精度が大幅に改善で きることが確認できた．このことから，本研究で提 案した，ファジィ因子分析手法により主観的評価值 のあいまい性を考慮した新たなハイブリッド交通機 関選択モデルが有効であることが伺える.

一方, モデル 2 と比べて, ファジィ因子分析から 算出された潜在因子を取り入れたモデル 3 は，精度 からみると，大きな差が見られないが，ファジィ潜 在因子の最小值を仮定した場合においては, 全ての ケースで自由度調整済み尤度比が若干高くなってい る．また，主観的評価值のあいまい性を反映し，幅 を持ったパラメータの推定值と自由度調整済み尤度 比を得られたことが特徴となっている.

モデル 2 とモデル 3 を比較すると, 通常の因子分 析結果を用いた場合 $(\gamma=0.0)$ の各潜在因子の推定パ ラメータ值が, ファジィ度 $(\gamma=0.6)$ を考慮した場合 の推定值区間に包含されていることが分かる. 


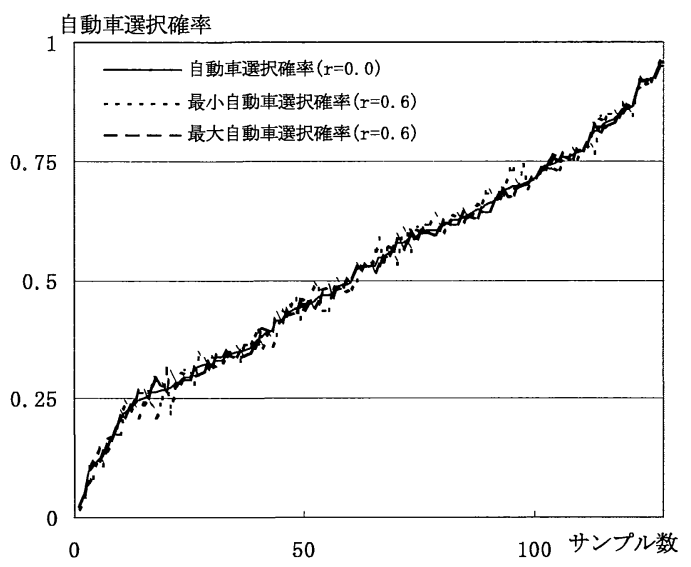

図-5 ケース 1 個人別の最小と最大自動車選択確率

\section{b）モデルパラメータの行動論的解釈}

交通サービス水準変数については，統計的に有意 となったのは, 自動車の遅れ時閒のみである. 交通 情報提供ダミーのパラメータも統計的に有意であっ た.このことから，交通機関選択に影響する客観的 な要因が, 自動車の遅れ時間と交通情報の提供であ ることが分かった。

一方，主観的評価值の影響を表す潜在因子につい てみると，ほとんどのパラメータが統計的に有意で あった．その中で，影響力が最も高いのは自動車の 交通情報に対する満足度であった。ただし，情報提 供がされない場合とゼロの遅れ時間が提供される場 合においては，NTS とそのフィーダーバスに対する 满足度の影響力が高くなっている.

特に, モデル 3 については, 情報提供がない場合 （ケース 1), 自動車の交通情報に対する満足度のフ アジィ推定值区間が $[0.632 ， 0.829]$, NTS とそのフ ィーダーバスに対する満足度のファジィ推定值区間 が $[0.640,0.606]$ となっていることから，ファジィ 潜在因子を取り入れることにより, 説明変数の影響 力が逆転する可能性があることを示唆している.

\section{c）情報提供による不確実性の減少効果分析}

図-5 と図-6に，主観的評価值のあいまい性に起因 すると思われる，ケース 1 と 3 における個人別の交 通機関選択確率の広がり（最小值, 最大值）を示し ている. 交通情報が提供されないケース 1 と比べて, 自動車の遅れ時間情報を提供したケース 3 では，選 択確率の変動幅が狭くなっていることが分かる.こ れは, 交通情報の提供が意思決定者の選択における 不確実性を減少させたためであると解釈することが できる.

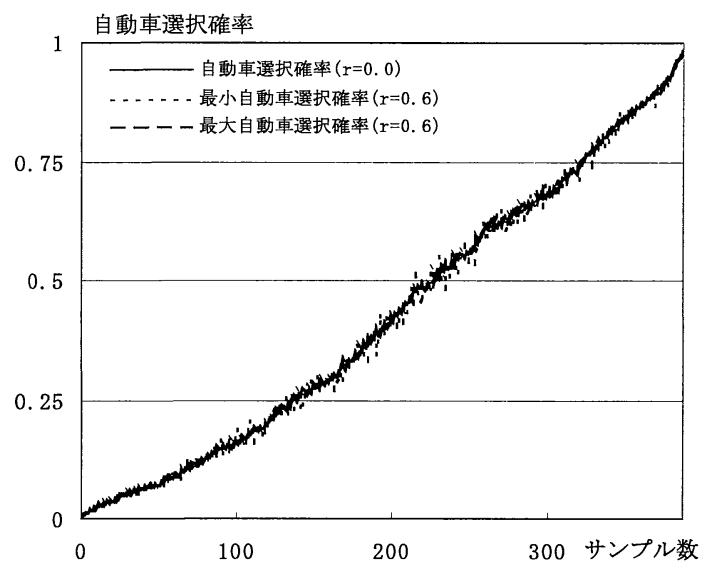

図-6 ケース 3 個人別の最小と最大自動車選択確率

しかし，今回の事例研究では，ファジィ因子分析 から，因子得点は区間で与えるファジィ数として算 出されたが, 離散選択モデルに取り入れる際に, 区 間の最大值と最小值をそれぞれ用いて推定を行った. 今後, 最大值と最小值をもった区間データをそのま ま離散選択モデルに取り入れるための推定手法の開 発が研究課題として残される.

\section{5. おわりに}

本研究では, 交通機関選択を対象に, 選択に影響 する利用者満足度という主観的評価値の 2 面性（個 人からみたあいまい性と個人間の変動）に着目し， あいまい性をファジィ因子分析手法により，個人間 の変動を離散選択モデルによりそれぞれ表現した新 たなハイブリッド離散選択モデルを提案した. 本研 究の成果を以下のようにまとめることができる.

1) 通常の因子分析と比べて, ファジィ因子分析手 法では主観的評価値のあいまい性を考慮するた め,「幅」をもつ相関行列を定義し,「幅」で与 える潜在因子を算出することができる、ファジ イ因子分析の結果, 普段あまり利用されていな いアストラムラインとそのフィーダーバスの評 価項目に対する主観的評価值は, 自動車の評価 項目に関する主観的評価值によりあいまい性が 相対的に多く含まれていることが確認できた. このことから，ファジィ因子分析による主観的 評価值のあいまい性を効果的に表現していると 解釈することができる.

2）前述の「幅」をもった潜在因子を交通機関選択 
モデルに取り入れて, 実証的分析を行った結果, モデルの精度が従来のモデルと比べて大幅に改 善することが分かった。このことは, 本研究で 提案した, 主観的評価値を考慮した新たな八イ ブリッド離散選択モデルの有効性を示している.

3）ファジィ因子分析手法により主観的評価值を取 り入れた交通機関選択モデルは, 従来の選択モ デルを特殊ケースとして含めることができ, 提 案したモデルの一般性が認められる.

4）異なる情報提供シナリオ（ケース）について分 析した結果, 交通情報の提供により, 意思決定 者の選択における不確実性が減少することが確 認できた。これまで，情報提供による移動時間 の短縮や交通機関の転換といった定量的な効果 を評価しているが, 意思決定の不確実性の低減 効果についてはその評価は課題として残されて きたと思われる.ここでの分析結果から, 本研 究で提案したモデルは, 意思決定の不確実性の 减少効果を評価するツールとして適用可能であ ることが分かる.

本研究では, 潜在因子の区間ファジィ数の最小值 と最大值のそれぞれに対して, ロジットモデルを推 定し, パラメータの違いを比較したが, 個別推定に よるモデルのスケールパラメータが異なってくる可 能性があり, 今後, 区間ファジィ数をそのまま活か した離散選択モデルの推定手法を開発することが今 後の研究課題として残されている.

\section{参考文献}

1) Ben-Akiva, M., McFadden, D., Train, K. and Walker, J.: Hybrid choice models: progress and challenges, Working paper, MIT, 2001.

2) Walker, J.L.: Extended discrete choice models: integrated framework, flexible error structures, and latent variables, Ph.D. Dissertation, MIT, 2001.

3) Walker, J. and Ben-Akiva, M.: Generalized random utility model, Mathematical Social Sciences, Vol.43, pp.303-343, 2002.

4) 森川高行, 佐々木邦明 : 主観要因を考慮した非集計離 散型選択モデル, 土木学会論文集, No.470/IV-20, pp.115-124, 1993.

5) Morikawa, T. and Sasaki, K.: Discrete choice models with latent variables using subjective data, In Ortuzar, J., Hensher, D. and Jara-Diaz, S. (eds), Travel Behavior Research : Updating the State of Play, Pergamon, pp.435455, 1998.

6) 河上省吾, 井上徹, 佐々木邦明 : 利用手段ごとの主観
的知覚構造の違いを考慮した交通機関選択モデル, 土 木計画学研究・論文集, No.16, pp.637-642, 1999.

7) Fukuda, D., Lee, E.H. and Morichi, S.: A comparative study on discrete choice models with choice set formation process : An application to travel mode choice, Proceedings of $9^{\text {th }}$ WCTR Conference in Seoul, Korea, CD-ROM, 2001.

8) 藤井聡, 竹村和久：リスク態度と注意一状況依存焦点 モデルによるプレーミング効果の計量分析, 行動計量 学, Vol.28, No.1, pp.9-17, 2001.

9) 藤井聡, トミー・ヤーリング: 交通需要予測における SP データの新しい役割, 土木学会論文集, No.723/IV-58, pp.1-14, 2003.

10) Fujii, S. and Gärling, T.: Application of attitude theory for improved predictive accuracy of stated preference methods in travel demand analysis, Transportation Research Part A, Vol.37, No.4, pp.386-402.

11) 吉川歩 : ファジィ評定とメンバーシップ関数同定法, 日本ファジィ学会誌, Vol.10, No.2, pp.201-209, 1998.

12）中森義輝 : 感性データ解析, 感性情報処理のためのフ アジィ数量分析手法, 森北出版, 2000.

13）中森義輝, 佐藤和明, 和多田淳三: ファジィデータの 因子空間モデル，日本ファジィ学会誌，Vol.9, No.1, pp.99-107, 1997.

14）中森義輝, 川中愛 : 因子空間におけるあいまいさの表 現, 日本ファジィ学会誌, Vol.11, No.5, pp.797-807,

15) Yabuuchi, Y., Watada, J. and Nakamori, Y.: Fuzzy principal component analysis for fuzzy data, Proceedings of FUZZ-IEEE, Vol.2, pp.1127-1132, Barcelona, Spain, July 1-7, 1997.

16）古殿幸雄，奥田徹示，浅居喜代治，杉浦寅彦：ファジ イ観測データを用いる主成分分析, 日本ファジィ学会, Vo1. 4, No. 3, pp. 120-137, 1992.

17) 北村隆一, 森川高行編著: 交通行動の分析とモデリン グ，技報堂出版，2002.

18) Dobson, R.: Towards the Analysis of attitudinal and behavioral responses to transportation system characteristics, Transportation, Vol.4, pp.267-290, 1975.

19) McFadden, D.: Rationality for economists? Journal of Risk and Uncertainty, Vol.19(1-3), pp.73-105, 1999.

20) Recker, W.W. and Golob, T.F.: Attitudinal modal choice model, Transportation Research, Vol.10, No.5-B, pp.299310, 1976.

21) Boxall, P.C. and Adamowicz, W.L.: Understanding heterogeneous preferences in random utility models : the use of latent class analysis, Staff Paper 99-02, University of Alberta, 1999.

22) Koppleman, F.S. and Lyon, P.K.: Travel choice behavior: Models of perceptions, feelings, preference, and choice, 
Transportation Research Record, No.765, pp.26-33, 1980.

23) Koppleman, F.S. and Lyon, P.K.: Attitudinal analysis of work/school travel, Transportation Science, Vol.25, No.3, pp.26-33, 1981.

24) Lovelock, C.H.: Modeling the modal choice decision process, Transportation, Vol.4, pp.253-265, 1975.

25) Dobson, R. and Tischer, M.L.: Comparative analysis of determinants of modal choice by central business district workers, Transportation Research Record, No.649, pp.7-14, 1977.

26）武藤慎一, 上村高大, 高木朗義 : ファジィ効用を用い たレクリエーション施設整備の便益評価, 日本ファジ イ学会誌, Vol.13, No.6, pp.662-671, 2001.

27) 藤原章正, 張峻屹, 岡村敏之 : ファジィ理論に基づく $\mathrm{C} \mathrm{V}$ 調查分析法による住区内街路整備の評価, 都市計 画論文集, No.38-3, 505-510, 2003.

28）秋山孝正, 佐佐木鋼: ファジィ推論と交通行動の記述, 交通工学, Vol.23, No.3, pp.22-27, 1988.

29) Lee, B.J., Namgung, M., Sung, S.R. and Fujiwara, A.: Route choice behavior model using fuzzy inference, Selected Proceedings of $9^{\text {th }} W C T R, 2003$ (in press).

30) 高羽俊光, 秋山孝正 : ソフトコンピューティングを 利用した交通行動記述サブモデル, 土木計画学研究 • 論文集, No. 17, 701-709, 2000.

31) Lotan, T. and Koutsopoulos, H.N.: Models for route choice behavior in the presence of information using concepts form fuzzy set theory and approximate reasoning, Transportation, Vol.20, pp.129-156, 1993.

32) 水谷香織, 秋山孝正 : ファジィ推論とロジットモデル によるハイブリットモデルの検討, 土木計画学研究・ 論文集, Vol.18, No.3, pp.509-516, 2001.

33）秋山孝正, 高羽俊光, 水谷香織 : ナビゲーションのた めのファジィ交通行動分析, 日本ファジィ学会誌, Vol.11, No.2, pp.205-214, 1999.

34) Vythoulkas, P.C. and Koutsopoulos, H.N.: Modeling discrete choice behavior using concepts from fuzzy set theory, approximate reasoning and neural networks, Transportation Research Part C, Vol.11, pp.51-73, 2003

35) 菊地慎也, 宇野伸宏 : 推定旅行時間のあいまいさがト リップ計画に及ぼす影響の測定方法 : 可能性理論の適 用, 日本ファジィ学会誌, Vol.11, No.2, pp.233-245, 1999.

36）柳井晴夫, 繁桝算男, 前川眞一, 市川雅教: 因子分析, 朝倉書店, 1990.

37) Jang, J.S.R., Sun, C.T. and Mizutani, E.: Neuro-Fuzzy and Soft Computing, International edition, Prentice-Hall International Inc., New Jersey, 1997.

38）藤原章正, 中村文彦, 佐藤和彦, 神田佑亮: 旅行時間 情報の提供が個人の交通機関選択効用に及ぼす影響, 土木計画学研究・論文集, Vol.18, No.4, pp.637-642, 2001.

39) Teodorović, D.: Fuzzy logic systems for transportation engineering: the state of the art, Transportation Research Part A, Vol.33, pp.337-364, 1999.

40) Dubois, D. and Prade, H.: Fuzzy sets and probability : Misunderstandings, bridges and gaps, Proceedings of the Second IEEE Conference on Fuzzy Systems, San Francisco, pp.1059-1068, 1993.

41) Kikuchi, S.: Treatment of uncertainty study of transportation: fuzzy set theory and evidence theory, Journal of Transportation Engineering, Vol.124, No.1, 1998.

42) Lee, B.J., Fujiwara, A., Sugie, Y. and Namgung, M.: A sequential method for combining random utility model and fuzzy inference model, Journal of Advanced Computational Intelligence and Informatics, Vol.7, No.2, 200-206, 2003.

43) 水本雅晴: ファジィ理論とその応用, サイエンス社, 1990.

44）原田昇，森川高行，屋井鉄雄 : 交通行動分析の展開と 課題, 土木学会論文集, No.470/IV-20, pp.97-104, 1993.

(2003.6.6 受付)

\section{HYBRID DISCRETE CHOICE MODEL INCORPORATING FUZZINESS OF SUBJECTIVE EVALUATION DATA}

\section{Backjin LEE, Akimasa FUJIWARA, Junyi ZHANG and Yoriyasu SUGIE}

Conventional factor analysis is difficult to satisfactorily represent fuzziness in subjective evaluation data. This paper therefore attempts to tackle this issue by applying a factor analysis based on fuzzy theory. Moreover, a new discrete choice model (called hybrid discrete choice model) is proposed by incorporating fuzzy latent factors calculated from the above-mentioned factor analysis. Reflecting the influence of fuzziness, utility functions of hybrid discrete choice model are defined as those having interval values. An empirical study, using stated preference data for choice of travel mode under information provision, confirmed the effectiveness of factor analysis based on fuzzy theory and the hybrid discrete choice model. 